\title{
Heliquinomycin, a New Inhibitor of DNA Helicase, Produced by Streptomyces sp. MJ929-SF2
}

\section{Taxonomy, Production, Isolation, Physico-chemical Properties and Biological Activities}

\author{
Makoto Chino*, Kiyohiro Nishikawa ${ }^{\dagger}$, Maya Umekita, Chigusa Hayashi, \\ Takako Yamazaki, Toshio Tsuchida, Tsutomu Sawa, \\ Masa Hamada and Tomio Takeuchi \\ Institute of Microbial Chemistry, \\ 3-14-23 Kamiosaki, Shinagawa-ku, Tokyo 141, Japan \\ †Pharmaceuticals Group, Nippon Kayaku Co. Ltd., \\ 31-12 Shimo 3-Chome, Kita-ku, Tokyo 115, Japan
}

(Received for publication February 20, 1996)

\begin{abstract}
Heliquinomycin was isolated as a part of a program designed to find inhibitors of DNA helicase from microbial sources. It was purified from the culture broth of Streptomyces sp. MJ929-SF2 by solvent extraction and serial chromatographies of centrifugal partition chromatography, Sephadex LH-20 and Capcell Pak C18 (HPLC). The isolated red powder was analyzed to have the molecular formula of $\mathrm{C}_{33} \mathrm{H}_{30} \mathrm{O}_{17}$. It inhibited partially purified DNA helicase from HeLa cell in a noncompetitive manner with the inhibition constant $(K i)$ of $6.8 \mathrm{~mm}$.

Heliquinomycin exhibited biological activity against microorganisms including MRSA, and cultured cell lines.
\end{abstract}

DNA helicase is essential in the processes of DNA replication, repair, recombination and transcription by unwinding of double-stranded DNA to its reactive single strand form. This is an energy requiring process driven by the hydrolysis of deoxynucleaside $5^{\prime}$-triphosphate ${ }^{1)}$. All known DNA helicases have been found to process intrinsic DNA-dependent ATPase activity ${ }^{2 \sim 4)}$.

DNA helicase was discovered for the first time in 1976 in $E$. coli ${ }^{5}$. Most of the DNA helicases need ssDNA adjacent to the duplex region to be unwound, with the notable exception of the SV40 T antigen ${ }^{6)}, E$. coli helicase ${ }^{7)}$, and $E$. coli $\operatorname{Rec}^{8)}$ which are also able to unwind fully duplex linear DNA.

In the course of screening for inhibitors of DNA helicase, we discovered a novel compound named heliquinomycin from the culture broth of Streptomyces $\mathrm{sp}$. MJ929-SF2. In this communication, we report the taxonomy of the producing culture as well as the fermentation, production, isolation, physico-chemical properties and biological activities of heliquinomycin. Determination of heliquinomycin structure will be described in the following paper ${ }^{9}$.

\section{Materials and Methods}

Microorganism

The heliquinomycin producting organism, strain MJ929-SF2 was isolated from a soil sample collected at
Hachiohji, Tokyo, Japan and has been deposited in the National Institute of Bioscience and Human-Technology, Agency of Industrial Science and Technology, Ministry of International Trade and Industry, Tsukuba, Japan under the accession number FERM P-14380.

\section{Partial Purification of Human DNA Helicase}

DNA helicase was prepared from $\mathrm{HeLa}$ cells. The logarithmically growing cells were collected and stocked at $-80^{\circ} \mathrm{C}$. The frozen cells were thawed on ice, and a nuclear extract fraction was prepared as described by Dignam et $a l .^{10)}$. Briefly, the nuclear extract protein was precipitated by slow addition of ammonium sulfate $(0.35 \mathrm{~g} / \mathrm{ml})$, with constant stirring. The mixture was stirred for an additional hour and the precipitate was

Fig. 1. Structure of heliquinomycin.

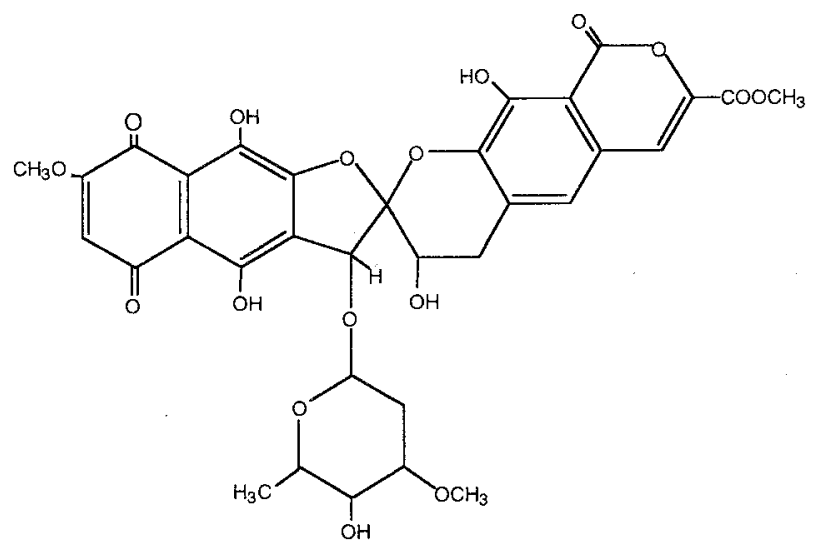


collected by centrifugation. The pellet was resuspended and dialyzed in buffer A ( $1 \mathrm{mM}$ PMSF; $1 \mathrm{~mm}$ sodium bisulfite; $20 \mathrm{~mm}$ HEPES, $\mathrm{pH} 8.0 ; 0.1 \mathrm{M} \mathrm{NaCl} ; 1 \mathrm{~mm}$ DTT; $1 \mathrm{~mm}$ EDTA and $20 \%$ glycerol). The fraction was passed through a Bio-Rex 70 column equilibrated with buffer $A$. The active fractions were precipitated with ammonium sulfate $(0.35 \mathrm{~g} / \mathrm{ml})$, again, as described above. The protein pellet was resuspended and dialyzed in buffer B (1 mM PMSF; $1 \mathrm{mM}$ sodium bisulfite; $50 \mathrm{mM}$ Tris- $\mathrm{HCl}, \mathrm{pH} 8.0 ; 50 \mathrm{~mm} \mathrm{KCl}$; 1 mм DTT; 1 mм EDTA and $10 \%$ glycerol) and stored at $-4^{\circ} \mathrm{C}$.

\section{DNA Helicase Assay}

DNA helicase activity was measured by the means of the release of $\alpha^{32} \mathrm{P}$-labelled DNA fragment (d(GTAAAACGACGGCCAGT)) from anealed circular M13mp18 DNA molecule. The reaction mixture $(10 \mu \mathrm{l})$ containing $20 \mathrm{~mm}$ Tris-HCl (pH 7.5); $8 \mathrm{mM} \mathrm{DTT;} 2 \mathrm{mM} \mathrm{MgCl}_{2}$; $2 \mathrm{~mm}$ ATP; $10 \mathrm{mM} \mathrm{KCl} ; 4 \%$ (wt/vol) sucrose; $80 \mu \mathrm{g} / \mathrm{ml}$ BSA; ${ }^{32}$ P-labelled helicase substrate $(1000 \mathrm{cpm})$ and the helicase fraction, was incubated at $37^{\circ} \mathrm{C}$ for 20 minutes. The reaction was terminated by the addition of $0.06 \%$ SDS, $2 \mathrm{~mm}$ EDTA, $1 \%$ glycerol and $0.02 \mathrm{mg} / \mathrm{ml}$ bromophenol blue at the final concentration. After further incubation at $37^{\circ} \mathrm{C}$ for 5 minutes the substrate and product were separated by electrophoresis on a $12 \%$ nondenaturing polyacrylamid gel. The gel was dried under vacuum and exposed to Hyperfilm with an intensifying screen for autoradiography. $\mathrm{The} \mathrm{IC}_{50}$ value is the concentration of inhibitor at $50 \%$ inhibition of enzyme activity.

\section{Fermentation}

The strain, MJ929-SF2, was inoculated into $110 \mathrm{ml}$ of seed culture medium consisting of galactose $2.0 \%$; dextrin 2.0\%; Bacto Soytone 1.0\%; corn steep liquor $0.5 \% ;\left(\mathrm{NH}_{4}\right)_{2} \mathrm{SO}_{4} 0.2 \%$ and $\mathrm{CaCO}_{3} 0.2 \%$ (pH 7.4) in a $500-\mathrm{ml}$ Erlenmeyer flask, and cultured by incubating at $27^{\circ} \mathrm{C}$ for 4 days on a rotary shaker $(180 \mathrm{rpm})$. Two $\mathrm{ml}$ of this seed culture were inoculated into $110 \mathrm{ml}$ of the same medium in a 500-ml Erlenmeyer flask and incubated at $27^{\circ} \mathrm{C}$ for 4 days on a rotary shaker $(180 \mathrm{rpm})$.

\section{Isolation}

The culture broth was separated into mycelial cake and culture filtrate by filtration. The mycelial cake was extracted with methanol. The extract was filtered and concentrated in vacuo to an aqueous solution. The solution was combined with the culture filtrate and extracted with an equal volume of butyl acetate. The active extract was concentrated to dryness under reduced pressure. The dried material was chromatographed on a silica gel column $(\times 50 \mathrm{w} / \mathrm{w}$ powder $)$ with a linear gradient 0 to $100 \%$ aqueous $\mathrm{MeOH}$. The active fractions were collected and evaporated to give a red powder. The powder was subjected to centrifungal partition chromatography using CPC-L.L.N model NMF (Sanki Engineering Limited) with a solvent system of $\mathrm{CHCl}_{3}-\mathrm{MeOH}$ -
$\mathrm{H}_{2} \mathrm{O}(5: 6: 4)$. The upper phase of the solvent was introduced by ascending method. By changing of the flow direction (descending method), the active fractions were eluted with the lower phase of the solvent system to give a red powder. The powder was applied onto Sephadex LH-20 (1 liter) and eluted with solvent mixture of $\mathrm{CHCl}_{3}-\mathrm{MeOH}(1: 1)$. The active fractions were concentrated under reduced pressure to give a red powder. The crude powder was purified by reverse phase HPLC using Capcell Pak C18 column (i.d. $2.0 \times 25 \mathrm{~cm}$ ) with a solvent mixture of $\mathrm{CH}_{3} \mathrm{CN}-50 \mathrm{mM} \mathrm{KH} \mathrm{KO}_{4} \mathrm{PO}_{4}(\mathrm{pH}$ 2.5 ) running at the flow rate of $8 \mathrm{ml} /$ minute. The active fraction was extracted with an equal volume of butyl acetate and evaporated to dryness to obtain pure heliquinomycin.

\section{Physico-chemical Properties}

UV absorption spectra were measured with a Hitachi U-3210 spectrophotometer. IR absorption spectra were obtained using a Hitachi I-5020 FT-IR spectrometer. Mass spectra were obtained with a JEOL JMS-SX 102 spectrometer. NMR spectra were recorded on a JEOL JNM-GX500 spectrometer. MP was determined on a Yanagimoto micro melting point apparatus. Optical rotation was measured with a Perkin-Elmer 241 polarimeter.

\section{Antimicrobial Activity}

The minimum inhibitory concentrations (MIC) of heliquinomycin were examined by serial agar dilution method using Mueller Hinton agar (Difco) for an antibacterial test which was incubated at $37^{\circ} \mathrm{C}$ for 18 hours $^{11}$.

\section{Antitumor Activity}

Tumor cells were incubated in 96-well plate for 24 hours prior to the addition of heliquinomycin into culture well at varied concentrations. After 2 to 3 days incubation at $37^{\circ} \mathrm{C}$, MTT reagent was added and further incubated for 4 hours. Growth inhibition activity was determined according to the standard MTT assay method ${ }^{12)}$ and $\mathrm{IC}_{50}$ was calculated.

Fig. 2. Scanning electron micrograph of strain MJ929-SF2. Bar represents $1.76 \mu \mathrm{m}$.

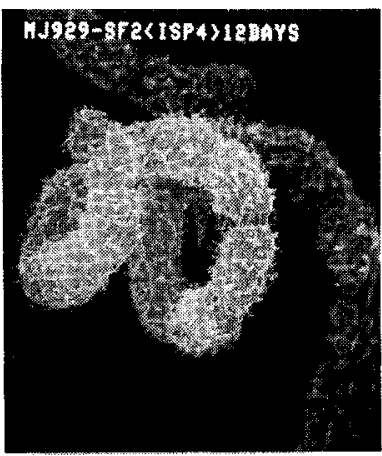


Table 1. Cultural characteristics of strain MJ929-SF2.

\begin{tabular}{|c|c|c|c|}
\hline Medium & Aerial mycelium & Growth & Soluble pigment \\
\hline Sucrose nitrate agar & White & $\begin{array}{l}\text { Bright brown } \\
\text { [4ge, Rose beigee] }\end{array}$ & None \\
\hline Glucose - asparagine agar & Thin, natural & $\begin{array}{l}\text { Red brown } \\
\text { [6pi, Brown mahogany] }\end{array}$ & Faint, brownish \\
\hline Glycerol - nitrate agar & None & $\begin{array}{l}\text { Grayish red purple } \\
{[8 \text { ng, Old wing }]}\end{array}$ & Faint, purple \\
\hline Starch agar & None & $\begin{array}{l}\text { Brownish purple } \\
\text { [8pg, Claret wing }]\end{array}$ & Faint, purple \\
\hline Calcium malate agar & None & Colorless & None \\
\hline Nutrient agar & None & $\begin{array}{l}\text { Yellowish brown } \\
{[3 \text { ni, Clove brown] }}\end{array}$ & Brownish \\
\hline Yeast extract - malt extract agar (ISP-2) & Silver gray & $\begin{array}{l}\text { Yellowish brown } \\
\text { [3ni, Clove brown] }\end{array}$ & Brownish \\
\hline Oatmeal agar (ISP-3) & Covert gray & $\begin{array}{l}\text { Pale brown } \\
{[51 \mathrm{~g}, \text { Cocoa brown }]}\end{array}$ & Purple \\
\hline Inorganic salts - starch agar (ISP-4) & Dk Covert gray & $\begin{array}{l}\text { Dark brownish purple } \\
\text { [8pl, Buegundy] }\end{array}$ & Purple \\
\hline Glycerol asparagine agar (ISP-5) & Ashes & $\begin{array}{l}\text { Brownish purple } \\
{[7 \mathrm{nl}-7 \mathrm{pl}, \text { Dk rose Brown to burgundy }]}\end{array}$ & Brownish \\
\hline Tyrosine agar (ISP-7) & Dk covert gray & $\begin{array}{l}\text { Red purple } \\
{[5 \mathrm{po}, \text { Chocolate brown }]}\end{array}$ & Brownish \\
\hline
\end{tabular}

Cultural characteristic were determined by the methods of SHIRLING and GoTTLIEB ${ }^{14)}$ and WAKSMAN ${ }^{15)}$.

Observation after incubation at $27^{\circ} \mathrm{C}$ for 21 days.

The color names used in the table were based on the Color Harmony Manual (Container Corporation of America).

Table 2. Physiological properties of strain MJ929-SF2.

\begin{tabular}{lc}
\hline Temperature range for growth $\left({ }^{\circ} \mathrm{C}\right)$ & $10 \sim 37$ \\
Optimum temperature $\left({ }^{\circ} \mathrm{C}\right)$ & $27 \sim 37$ \\
Formation of melanoid & + \\
Liquefaction of gelatin $\left(20^{\circ} \mathrm{C}\right)$ & + \\
Liquefaction of glucose peptone gelatin $\left(27^{\circ} \mathrm{C}\right)$ & + \\
Coagulation of milk $\left(37^{\circ} \mathrm{C}\right)$ & + \\
Peptonization of milk $\left(37^{\circ} \mathrm{C}\right)$ & + \\
Hydrolysis of starch & - \\
Reduction of nitrate & + \\
Decomposition of cellulose & - \\
Solution of calcium malate & - \\
\hline Physiolgical characteristics determined by the methods \\
of WaKsman ${ }^{15)}$. \\
$+:$ Utilized. \\
- Not utilized.
\end{tabular}

\section{Results and Discussion}

Taxonomy of the Producing Strain

Strain MJ929-SF2 produced branched substrate mycelia developing aerial hyphae which usually extended straightforward and had spiral spore chains with more than 50 spores measuring $0.93 \sim 0.99 \times 1.43 \mu \mathrm{m}$. The surface of conidia was spiny. Its shown in Fig. 2. The cultural characteristics of the strain MJ929-SF2 are summarized in Table 1. The color of vegetative growth was chocolate brown to burgundy. Soluble pigment color was brownish to purple. Melanoid pigments were
Table 3. Utilization of carbon sources of strain MJ929-SF2.

\begin{tabular}{lc}
\hline L-Arabinose & + \\
D-Xylose & + \\
D-Glucose & + \\
D-Fructose & + \\
Rhamnose & + \\
Sucrose & + \\
Raffinose & + \\
Lactose & + \\
Inositol & - \\
D-Mannitol & - \\
\hline
\end{tabular}

Carbohydrate utilization was investigated by using the procedure of Pridham and GotTLieb ${ }^{16}$.

+ : Utilized

- : Not utilized.

produced. The physiological properties of the strain MJ929-SF2 are summarized in Table 2. Utilization of carbon source by this strain is presented in Table 3. Analysis of the whole-cell hydrolysate of the strain indicated the presence of LL-diaminopimelic acid.

On the basis of the characterisitics described above, the strain MJ929-SF2 is assessed to belong to the genus Streptomyces.

Production and Isolation of Heliquinomycin

The strain of MJ929-SF2 was cultured and incubated in Erlenmeyer flasks at $27^{\circ} \mathrm{C}$ for 4 days on a rotary shaker. The time course of the production is shown in 
Fig. 3. The maximum production of heliquinomycin in the flask was obtained 4 days, thereafter the production slowly decreased with a pH change to acid. The flow disgram for the isolation is shown in Fig. 4. The yield of pure heliquinomycin was $129 \mathrm{mg}$ from 5 liters of culture filtrate.

Physico-chemical Properties of Heliquinomycin

The physico-chemical properties of heliquinomycin are summarized in Table 4. The molecular formula of heliquinomycin was determined to be $\mathrm{C}_{33} \mathrm{H}_{30} \mathrm{O}_{17}$ by HRFAB-MS. Heliquinomycin is soluble in DMSO, $\mathrm{MeOH}, \mathrm{CHCl}_{3}$ and EtOAc, but insoluble in $\mathrm{H}_{2} \mathrm{O}$,

Fig. 3. Time course of heliquinomycin production.

- Heliquinomycin, a packed cell volume, $\circ \mathrm{pH}$.
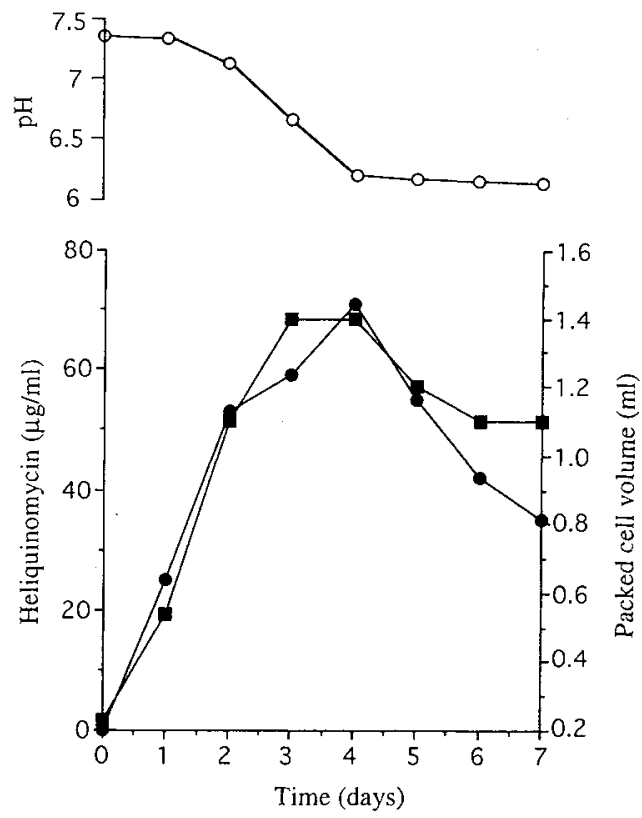

Mycelial growth was expressed as packed cell volume obtained after centrifugation of $10 \mathrm{ml}$ of the culture broth at $2,000 \mathrm{rpm}$ for 10 minutes. 1-propanol and $n$-hexane. The UV spectrum of heliquinomycin were similar to those of griseorhodins ${ }^{13}$.

Biological Activities of Heliquinomycin

In order to determine the inhibition kinetics to DNA helicase by heliquinomycin, the concentrations of enzyme substrate and heliquinomycin were varied in the reaction mixture. As shown in Fig. 5, inhibition of heliquinomycin against DNA helicase was in a noncompetitive manner. Its $K i$ value was determined to be $6.8 \mu \mathrm{M}$.

The antimicrobial activities of heliquinomycin were also examined and the results are shown in Table 5. Heliquinomycin showed strong inhibitory activity against Gram-positive bacteria strains including methicillin-resistant strains, but not against Gram-negative organisms or fungi.

The antitumor activity of heliquinomycin against tumor cell lines listed in Table 6 was examined. Heliquinomycin exhibited the growth inhibitory effect on several tumor cell lines. The concentrations inhibiting

Fig. 4. Isolation of heliquinomycin.

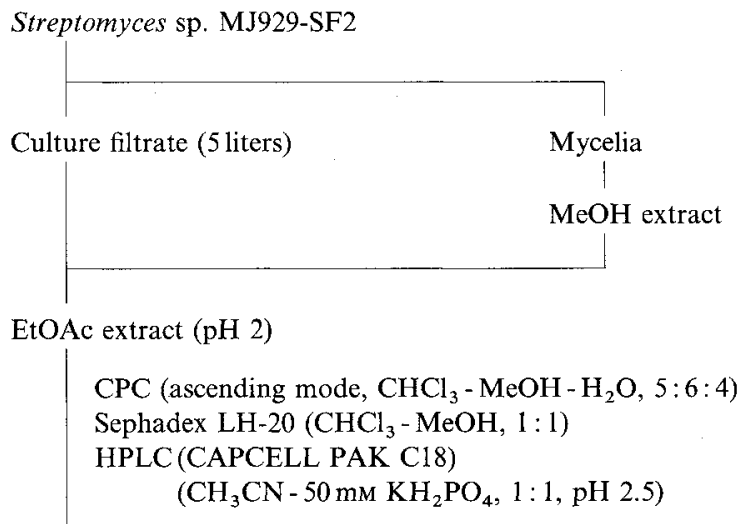

Heliquinomycin (126 mg)

Table 4. Physico-chemical propeties of heliquinomycin.

\begin{tabular}{|c|c|}
\hline Appearance & Red powder \\
\hline Molecular formula & $\mathrm{C}_{33} \mathrm{H}_{30} \mathrm{O}_{17}$ \\
\hline FAB-MS $(m / z)$ & $721(\mathrm{M}+\mathrm{Na})^{+}$ \\
\hline \multicolumn{2}{|l|}{ HRFAB-MS $(m / z)$} \\
\hline Calcd: & $698.1483\left(\right.$ as $\mathrm{C}_{33} \mathrm{H}_{30} \mathrm{O}_{17}$ ) \\
\hline Found: & $698.1486\left(\mathrm{M}^{-}\right)$ \\
\hline $\mathrm{UV} \lambda_{\max }^{\mathrm{MeOH}} \mathrm{nm}(\log \varepsilon)$ & $231(4.71), 312(4.30), 336(4.06), 507(3.86), 523(3.84), 540(3.87)$ \\
\hline$\lambda_{\max }^{\mathrm{MeOH}-\mathrm{HCl}} \mathrm{nm}(\log \varepsilon)$ & $230(4.15), 312(4.09), 336(1.03), 492(3.83)$ \\
\hline$\lambda_{\max }^{\mathrm{MeOH}-\mathrm{NaOH}} \mathrm{nm}(\log \varepsilon)$ & $224(4.78), 322(4.10), 379(4.06), 573(4.13)$ \\
\hline $\operatorname{IR} v_{\max }^{\mathrm{KBr}} \mathrm{cm}^{-1}$ & $3440(\mathrm{br}), 1720,1618,1458,1250$ \\
\hline MP (dec) & $213 \sim 214^{\circ} \mathrm{C}$ \\
\hline $\mathrm{Rf}$ value on TLC* & $0.71\left(\mathrm{CHCl}_{3}-\mathrm{MeOH}, 10: 1\right.$, silica gel $)$ \\
\hline \multirow[t]{2}{*}{ Solubility } & Soluble: DMSO, $\mathrm{MeOH}, \mathrm{CHCl}_{3}, \mathrm{EtOAc}$ \\
\hline & Insoluble: $\mathrm{H}_{2} \mathrm{O}, 1$-propanol, $n$-hexane \\
\hline
\end{tabular}

* Silica gel TLC (Merck Art. 5715): $\mathrm{CHCl}_{3}-\mathrm{MeOH}(10: 1)$. 
Fig. 5. Lineweaver-burk plot inhibition of DNA helicase by heliquinomycin.

$$
\bigcirc 13 \mu \mathrm{g} / \mathrm{ml}, \star 6.5 \mu \mathrm{g} / \mathrm{ml}, \bullet 3.25 \mu \mathrm{g} / \mathrm{ml}, \approx 0 \mu \mathrm{g} / \mathrm{ml}
$$

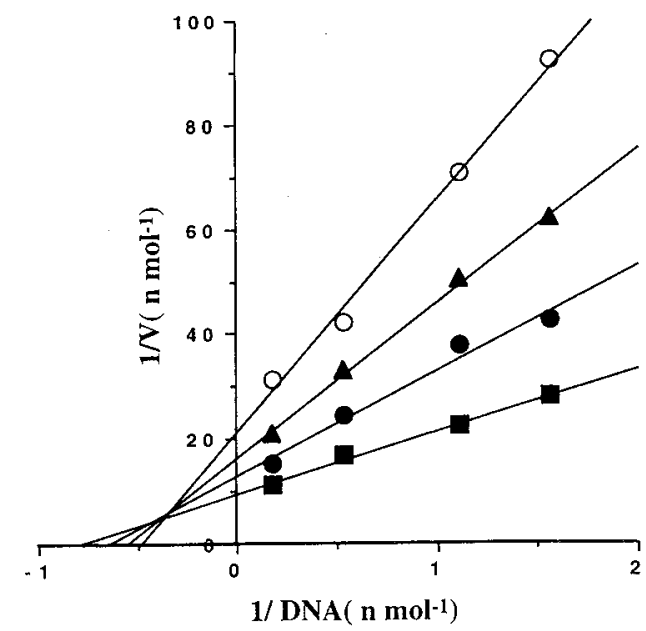

Inhibition of DNA helicase activity by heliquinomycin at various concentration was measured where the amount of enzyme substrate of ${ }^{32} \mathrm{P}$-labeled annealing circular DNA was varied.

Thus obtained inhibition kinetics of heliquinomycin were analyzed by the Lineweaver-burk plot and showed to be the mixed type of inhibition.

$50 \%$ of growth $\left(\mathrm{IC}_{50}\right)$ are shown in Table 6.

Heliquinomycin was discovered to be an inhibitor of DNA helicase, which is thought to be essential for DNA replication, repair, transcription and recombination. It showed antimicrobial and antitumor activity in vitro. We are now preparing to demonstrate whether heliquinomycin might show its antitumor and antimicrobial activity in animal models. Heliquinomycin did not show any toxicity $\left(\mathrm{LD}_{50}\right)$, in mice at $100 \mathrm{mg} / \mathrm{kg}$ with ip administration.

\section{References}

1) Geider, K. \& H. Hoffmann-Berling: Proteins controlling the helical structure of DNA. Ann. Rev. Biochem. 50: $233 \sim 260,1981$

2) Matson, S. W. \& K. A. Kaiser-Rogers: DNA helicase. Ann. Rev. Biochem. 59: 289 329, 1990

3) Thommes, P. \& U. Hubscher: Eukaryotic DNA helicase. FEBS Letter. 268: 325 328, 1990

4) Sung, P.; L. Prakash, S. Weber \& S. Prakash: The RAD3 gene of Saccharomyces serevisiae enconds a DNA-dependent ATPase. Proc. Natl. Acad. Sci. U.S.A. 84: $6045 \sim 6049,1987$

5) Abdel-Monem, M.; H. Durwald \& H. HoffmannBERLING: Enzymic unwinding of DNA. Eur. J. Biochem. 65: $441 \sim 449,1976$

6) SChefFner, M.; R. KinPPER \& H. STAHL: RNA unwinding activity of SV40 large $\mathrm{T}$ antigen. Cell 57: $955 \sim 963$, 1989
Table 5. Antimicrobial activities of heliquinomycin.

\begin{tabular}{|c|c|}
\hline Test organisms & $\operatorname{MIC}(\mu \mathrm{g} / \mathrm{ml})$ \\
\hline Staphylococcus aureus Smith & 0.1 \\
\hline S. aureus FDA209P & 0.1 \\
\hline S. aureus MS9610 & 0.39 \\
\hline S. aureus TY-00923(MRSA) ${ }^{\mathrm{a}}$ & 0.1 \\
\hline S. aureus Y-00936(MRSA) ${ }^{a}$ & 0.1 \\
\hline S. aureus Y-01022(MRSA) ${ }^{\mathrm{a}}$ & $<0.05$ \\
\hline S. aureus TY-01806(MRSA) ${ }^{\mathrm{a}}$ & $<0.05$ \\
\hline Micrococcus luteus FDA 16 & 0.2 \\
\hline M. luteus IFO 3333 & 0.1 \\
\hline M. luteus PIC 100I & 0.39 \\
\hline Bacillus anthracis & 0.1 \\
\hline B. subtilis NRRL B-558 & 0.1 \\
\hline B. subtilis PCI 219 & 0.1 \\
\hline B. cereus ATCC 10702 & 0.1 \\
\hline Corynebacterium bovis 1810 & 0.39 \\
\hline Escherichia coli NIHJ & 100 \\
\hline E. coli $\mathbf{K}-12$ & $>50$ \\
\hline Shigella dysenteriae JS1910 & $>50$ \\
\hline Salmonella typhi $\mathrm{T}-63$ & $>50$ \\
\hline Proteus vulgaris OX19 & $>50$ \\
\hline Serratia marcescens & $>50$ \\
\hline Pseudomonas aeruginosa A3 & $>50$ \\
\hline P. aeruginosa $\mathrm{GN} 315$ & $>50$ \\
\hline Klebsiella pneumoniae PCI602 & $>50$ \\
\hline Mycobacterium smegmatis ATCC $607^{b}$ & $>50$ \\
\hline Candida albicans 3147 & $>100$ \\
\hline
\end{tabular}

Mueller Hinton agar (Difco) $37^{\circ} \mathrm{C} 18$ hours.

a MRSA: Methicillin-resistant Staphylococcus aureus.

b $37^{\circ} \mathrm{C} 42$ hours.

Table 6. Growth inhibition of cultured cell lines by heliquinomycin.

\begin{tabular}{lc}
\hline \multicolumn{1}{c}{ Cells } & $\mathrm{IC}_{50}(\mu \mathrm{g} / \mathrm{ml})$ \\
\hline HeLa S3 & 1.6 \\
L1210 leukemia & 0.97 \\
IMC carcinoma & 1.56 \\
B16 meranoma & 0.89 \\
FS-3 fibrosarcoma & 0.83 \\
\hline
\end{tabular}

Growth inhibition activity was determined according to the MTT assay method.

7) Runyon, G. T. \& T. M. Lohman: Escherichia coli helicase II (UvrD) protein can completely unwind fully duplex linear and nicked circular DNA. J. Biol. Chem. 264: $17502 \sim 17512,1989$

8) UmezU, K.; K. Makayama \& H. Nakayama: Escherichia coli RecQ protein is a DNA helicase. Proc. Natl. Acad. Sci. U.S.A. 87: 5363 5367, 1990

9) Chino, M.; K. Nishikawa, M. Umekita, T. Tuchida, R. Sawa, H. Nakamura, H. Naganawa, Y. Muraoka, T. Sawa \& T. TaKeUChI: J. Antibiotics in preparation.

10) Dignam, J. D.; R. M. Lebovitz \& R. G. Roeder: Accurate transcription initiation by RNA poliymarase II in a soluble extract from isolated mammalian nuclei. Nucleic Acid. Res. 11: 1475 1489, 1983

11) Goto, S. et al.: MICs were accoding to the standard method of Japan Society of Chemotherapy. Chemo- 
thrapy (Tokyo) 29: 76 79, 1981 (in Japanese)

12) Mosmann, T.: Rapid colorimetric assay for cellular growth and survival: application to proliferation and cytotoxicity assays. Immuno. Methods. 65: 55 63, 1983

13) Eckardt, K.; H. Thrum, G. Bradler \& R. Fueguner: Griseorhodins, a new group of Actinomysete dyes acting as antibiotics. Antibiotiki 10: 603 612, 1965

14) Shirling, E. B. \& D. Gottlieb: Methods for charac- terization of Streptomyces species. Int. J. Syst. Bacteriology 16: $313 \sim 340,1996$

15) WaKsman, S. A.: Classification, identification and description of genera and species. The Actiomycetes, Vol. II, The Willams and Wilkins Co., Baltimore, 1961

16) Pridham, T. G. \& D. GotTlieb: The utilization of carboon compounds by some Actinomycetales as an aid for species determinetion. J. Bacteriology 56: $107 \sim 114,1948$ 